\title{
INTERNATIONAL WATERSHED TECHNOLOGY: IMPROVING WATER QUALITY AND THE ENVIRONMENT
}

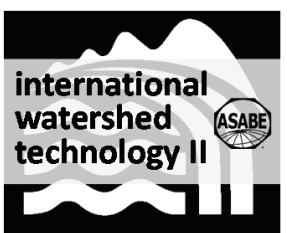

\author{
E. W. Tollner, K. R. Douglas-Mankin
}

\begin{abstract}
This article introduces a collection of papers from the fourth biennial ASABE 21st Century Watershed Technology Conference and Workshop: Improving Water Quality and the Environment, held in Hamilton, New Zealand, on November 3-6, 2014. This Special Collection consists of three articles selected from the 47 meeting papers. The technical presentations at the conference focused on solving spatial and temporal water quality and quantity problems and addressed topics such as watershed management in developing countries, water quality standards, agricultural best management practice (BMP) effectiveness, emerging problems, impact of extreme weather conditions, biological monitoring, increasing stakeholder involvement, political and economic implications, watershed implementation planning, forest and rangeland water quality issues, and water resources education. At first glance, these topics seem quite diverse. A more detailed look suggested that the "big data" and data mining themes of the last conference in Bari, Italy, continued to develop.
\end{abstract}

Keywords. Data processing, Modeling, Research, Water quality, Water quantity.

$\mathrm{T}$ ollner and Douglas-Mankin (2013), in introducing the 2013 ASABE Collection on International Watershed Technology, noted that "During the past decade, watershed science and engineering have advanced rapidly with the development and application of expanded knowledge and cutting-edge technologies in environmental monitoring, modeling, and analysis. While these approaches have solved many critical problems, many more challenges remain." In the intervening two years, both advances and challenges have continued.

The 21st Century Watershed Technology Conference and Workshop: Improving Water Quality and the Environment held in Hamilton, New Zealand, on November 3-6, 2014, highlighted recent advances in science and engineering research and their applications to address international water quality and environmental issues. Sponsors included ASABE; the Texas Institute for Applied Environmental Research (TIAER) at Tarleton State University, Stephenville, Texas; the Environmental Research Institute of the University of Waikato, Hamilton, New Zealand; the National Institute of Water and Atmospheric Research (NIWA) of New Zealand; the University of Florida; and the

Submitted for review in January 2016 as manuscript number NRES 11735; approved for publication by the Natural Resources \& Environmental Systems Community of ASABE in March 2016.

The authors are Ernest W. Tollner, ASABE Fellow, Professor, Department of Biological and Agricultural Engineering, University of Georgia, Athens, Georgia; Kyle R. Douglas-Mankin, ASABE Member, Senior Hydrologist, Everglades Program Team, U.S. Fish and Wildlife Service, Boynton Beach, Florida. Corresponding author: Ernest W. Tollner, 117 Driftmier Engineering Center, University of Georgia, Athens, GA 30602-4435; phone: 706-542-3047; email: btollner@engr.uga.edu.
USDA Agricultural Research Service (USDA-ARS). It was the fourth similarly themed ASABE-sponsored international scientific conference that highlighted recent watershed technology research and development to address the world's water quality and quantity problems. The program consisted of a two-day Soil and Water Assessment Tool (SWAT) modeling workshop followed by 2.5 days of plenary and research presentations and posters (http://watershedtech. org/documents/WatershedTechConferenceProgramme_Fin al_000.pdf). Keynote speakers were Dr. Liz Wedderburn (Āg Research, New Zealand), Dr. Gary Jones (e-Water Australia), and Dr. Mark R. Walbridge (USDA-ARS). The 24 concurrent sessions included 100 oral presentations in addition to a session with 13 posters. The resulting 47 conference papers are available in the ASABE Technical Library (http://elibrary.asabe.org).

This article introduces a Special Collection of three peer-reviewed journal articles published in Transactions of the ASABE and Applied Engineering in Agriculture. These articles were selected from the 47 papers presented at the conference. This introduction provides a perspective on the articles as examples of the increasing analysis, interpretation, and application of "big data" and data mining in hydrological sciences and engineering.

\section{WATERSHED TECHNOLOGY APPLICATIONS OF BIG DATA AND DATA MINING}

"Big data" generally refers to the collection, storage, processing, analysis, and visualization of huge data sets that may defy the use of traditional data-handling methods. As climatological, geophysical, ecological, socioeconomic, and management data become available at unprecedentedly large spatiotemporal extents and fine spatiotemporal resolu- 
tions, natural resource and environmental scientists and engineers are developing big data tools by necessity. This Special Collection provides several such examples.

Trotochaud et al. (2015) realized the need to process large climate datasets for use in common spatial models. They described a method to quickly obtain future climate data over a broad range of scenarios and timescales from the Intergovernmental Panel on Climate Change AR4 and AR5 model families using the MarkSim DSSAT Weather Generator and a Microsoft Excel VBA macro. The final result was a formatted par file for use in the CLIGEN (CLImate GENerator) weather-data simulator within the Water Erosion Prediction Project (WEPP) model. Ultimately, the method was modified to create continuous daily data for use with SWAT. The final product was an automated spreadsheet with a simple user interface that imports, analyzes, and generates climate input files for the WEPP and SWAT models. Thus, we see the data mining theme of the Bari, Italy, conference (Tollner and Douglas-Mankin, 2013) and movement into increasingly sophisticated big data approaches characterizing contemporary approaches to hydrologic research. The increased availability and capacity of these models to simulate defined hydrologic and water quality situations bodes well for enhanced academic learning environments as well.

Land users and managers require decision support tools (DSTs) that enable them to determine optimal strategies to reduce losses of contaminants from land to freshwater. McDowell et al. (2016) describe a farm-scale tool for compiling, processing, and visualizing large amounts of data for optimizing the cost and effectiveness of contaminant mitigation strategies. The MitAgator DST estimates farm-scale losses of nitrogen, phosphorus, sediment, and fecal indicator bacteria $(E$. coli $)$ and allows users to test the costeffectiveness of different strategies to mitigate losses, thereby identifying the least-cost strategy to achieve the water quality target.

Availability of increased amounts of data also creates opportunities for data mining to explore inter-relationships between and among environmental state and process variables. Woodward et al. (2016) describe techniques to determine sources and delivery mechanisms in mesoscale New Zealand watersheds. They analyzed correlations between coarser-resolution (monthly) water quality concentrations and higher-resolution (continuous) streamflow time series data across 26 catchments using several statistical approaches. Their results used combined analysis of water quality and streamflow data to separate the influence of groundwater and near-surface water sources on stream water quality. They demonstrated the importance of nearsurface flow paths and sources for several constituents and deeper groundwater sources for other constituents. Subsequent data stratification was used to explain the source of nitrate-nitrogen or orthophosphate trends, in some catchments, due to either historical or recent land use changes. These results highlight the value of combined analysis of water quality data with river flow records.

Other notable examples involving extensive data collection and analysis included work from Australia (Shrestha et al. (2014), western France (Baures et al., 2014), and South Korea (Jiang et al., 2014). The ability to collect and analyze big data is diffusing from developed countries to developing countries. The conference included papers and presentations from nearly every continent. These analyses are guiding decisions and educational efforts to reduce soil erosion and improve water quality and water conservation.

\section{Concluding Statements}

The big data theme was not limited to the three papers selected to appear in this Special Collection. Approximately $20 \%$ of the conference papers addressed database development, artificial intelligence applications, or other spatial modeling applications in New Zealand and around the world. Other papers chronicled the effectiveness of applying conservation practices for soil loss reduction and improved water conservation. Most of the presented papers reside in the ASABE Technical database under " 21 st Century" Conference Papers. The collection of conference papers demonstrates the increased use of sophisticated modeling approaches around the world.

\section{REFERENCES}

Baures, E., Thomas, O., \& Pitois, F. (2014). Watershed influence on factors responsible of cyanobacteria proliferation episodes in lacustrine waters (Brittany, western France, Europe). Presented at the 21 st Century Watershed Technology Conference. St. Joseph, MI: ASABE.

Jiang, M., Park, J.-H., Kim, N.-Y., Jeong, K., Hwang, S.-J., \& Kim, S.-H. (2014). A database approach to national aquatic ecological monitoring program in Korea. Presented at the 21 st Century Watershed Technology Conference. St. Joseph, MI: ASABE.

McDowell, R. W., Lucci, G. M., Peyroux, G., Yoswara, H., Brown, M., Kalmakoff, I., ... and Risk, J. (2016). An initial assessment of MitAgator: A farm-scale tool to estimate and mitigate the loss of contaminants from land to water. Trans. ASABE, 59(2), 571577. http://dx.doi.org/10.13031/trans.59.11192

Shrestha, M. K., Recknagel, F., Frizenschaf, J., \& Meyer, W. (2014). Simulation of nutrient loadings from the rural Cox Creek watershed (South Australia) by SWAT as a prerequisite for landuse specific scenario analysis. Presented at the 21st Century Watershed Technology Conference. St. Joseph, MI: ASABE.

Tollner, E. W., \& Douglas-Mankin, K. R. (2013). International watershed technology: Solving spatial and temporal water quality and quantity problems. Trans. ASABE, 56(6), 1353-1356. $\mathrm{http} / / / \mathrm{dx}$.doi.org/10.13031/trans.56.10535

Trotochaud, J., Flanagan, D. C., \& Engel, B. A. (2016). A simple technique for obtaining future climate data inputs for natural resource models. Appl. Eng. Agric., 32(3), (in press). http://dx.doi.org/10.13031/aea.29.10993

Woodward, S. J. R., Stanger, R., \& Hill, R. B. (2016). Flow stratification of river water quality data to elucidate nutrient transfer pathways in mesoscale catchments. Trans. ASABE, 59(2), 563-569. http://dx.doi.org/10.13031/trans.59.11145 